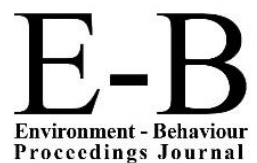

Environment - Behaviour
Procecdings Journal

\section{CSSR 2018}

https://cssr.uitm.edu.my/2018/

5th International Conference on Science and Social Research

Le Meridien Kota Kinabalu Hotel, 5 - 6 December 2018

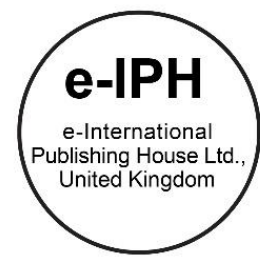

\title{
Design Feature of Local Traditional Pelangi Cloth
}

\author{
Mohd Azhar Samin \\ Faculty of Art \& Design, \\ Universiti Teknologi MARA, 40450 Shah Alam, Selangor, Malaysia \\ azharsamin64@gmail.com \\ Tel: +6019-8571964
}

\begin{abstract}
This paper is a discussion on how the design features of local traditional Pelangi cloth. The investigation is to determine the characteristic of the cloth that was designed. Most of this kind of textile artefacts were sustained and preserved at a few local museums. This study established the selected Pelangi cloths from several examples so that the analysis was conducted. The design illustrated certain similarity from the other type of local traditional cloth. Most of the design features were mainly derived from local elements. The combination of the designs significantly represented the identity of local traditional Pelangi cloth for this country.
\end{abstract}

Keywords: Design; Feature; Local Pelangi Cloth; Motifs

eISSN: 2398-42870 2020. The Authors. Published for AMER ABRA cE-Bsby e-International Publishing House, Ltd., UK. This is an open access article under the CC BYNC-ND license (http://creativecommons.org/licenses/by-nc-nd/4.0). Peer-review under responsibility of AMER (Association of Malaysian Environment-Behaviour Researchers), ABRA (Association of Behavioural Researchers on Asians) and cE-Bs (Centre for Environment-Behaviour Studies), Faculty of Architecture, Planning \& Surveying, Universiti Teknologi MARA, Malaysia. DOI: https://doi.org/10.21834/ebpj.v5iSl3.2535

\subsection{Introduction}

Pelangi cloth is one of the three easiest ways of resist techniques but still has the speciality. The Pelangi is a Malay word which means like the colours of a rainbow that has many colours. It starts with a piece of empty cloth which then needs to be bound and tied to the design that has been determined with the fibre straps to prevent it from penetrating of the colour Peacock, (1977). The cloth that has been strapped may be dyed once or dyed several times to produce a colour effect. Tritik is also a special technique in the finer Pelangi cloth that is found around Southeast Asia. It is a running stitches technique on the surface of the cloth then tightened, which will give a colourless effect on a certain small part. This Tritik technique is commonly used in combination with bound and tied dyeing techniques in single colour effect fabric.

\subsection{Literature Review}

In the past, art and appreciation for the manufacture of artistic textile were further expanded through the support of the Malay Rulers and the Palace as patron for the industry. According to Aziz (2006), Malay Rulers in ancient times were concerned about the development of local art and culture. Many of the Malay artisan at that time was employed in the courtroom under the patronage of the Sultan, Queen and palace chief. These royal and aristocrats are not only encouraging but also contributing beautiful motifs, designs and ornaments to artisans who are well-versed in designing and creativity in their respective fields. Samin (2015) stated about these

eISSN: 2398-4287C 2020. The Authors. Published for AMER ABRA cE-Bsby e-International Publishing House, Ltd., UK. This is an open access article under the CC BYNC-ND license (http://creativecommons.org/licenses/by-nc-nd/4.0/). Peer-review under responsibility of AMER (Association of Malaysian Environment-Behaviour Researchers), ABRA (Association of Behavioural Researchers on Asians) and cE-Bs (Centre for Environment-Behaviour Studies), Faculty of Architecture, Planning \& Surveying, Universiti Teknologi MARA, Malaysia.

DOI: https://doi.org/10.21834/ebpj.v5iSI3.2535 
beautiful designs, and delicate textiles often belong to kings and nobles for various purposes. Like the Pelangi cloth, in ancient times was often used as a garment and decoration in the daily life of the Malay rulers and nobility. This textile is often used and worn in attending various occasions and ceremonies in certain official customs. In addition, it is also often used as a gift and gift to the people who have served the King and the State. The beautiful and refined Pelangi cloth is also a gift in the form of full set garment and souvenirs to the guests of the King who come to the palace for various affairs and purposes.

Pelangi cloth is a kind of local traditional textiles with Malay motifs and designs. Produced by bound and tapered or running stitches technique on the surface of the fabric with a colourful colouring effect and then finishing with the paintbrush (Colek) technique. Often used as a complement to the garment, palace decorations, and souvenirs among Malay Kings around the 17th to 18th centuries. This textile had been manufactured in Perak and Terengganu around the 18th century and in Kelantan in the 19th century. It was popular as a Malaya garment around the beginning of the 20th century. Unfortunately, the manufacturing of this textile began to decline after the 1930s due to the development of the Batik Blok textile industry followed by the Batik Skrin textile industry introduced around the 1920s. Today, society is generally not exposed. It recognizes design features and motifs on traditional Pelangi cloths compared to other types of motifs on other local traditional textiles, especially those still under development. The situation caused a misinterpreting and a lack of understanding that raised the question of how the design features and motifs on traditional Pelangi cloths in the country. Samin (2011) specified that:

The beauty and specialities of the local traditional textiles can be seen in motifs and designs as well as their form and functions. However, the features contained in motifs and designs and the form and function of the traditional Pelangi cloth are still blurred and have never been shown for general knowledge as compare to Batik cloth, Songket cloth, and Pua cloth". (p. 109)

\subsection{Methodology}

The research objectives are to review the traditional Pelangi cloth design features in this country. Besides, to identify the types of the traditional Pelangi cloth motifs that still exist and have not been highlighted to the community. This study is important because to avoid incorrect interpretation of the local community today about the traditional Pelangi cloth of the local heritage compared to the outside textile. It is also to educate society to know more closely and be sensitive to the local design features and types of traditional Pelangi cloth. In order to identify and know more about the traditional designs and motifs or patterns of traditional Pelangi cloths, the field study with photos documentation as well as design analysis approaches had been implemented. A few field study sessions were carried out; aim to track and record in the form of photographs of the traditional Pelangi cloth artefacts that are still available and stored in several museums and galleries around Malaysia Peninsular. Among the museums visited are the Kelantan State Museum, Terengganu State Museum, National Textile Museum, Selangor State Museum and RA Fine Art Gallery. In the field study and photo documentation method, various traditional Pelangi cloth artefacts have been recorded by the researcher as a photo documentation study. The study of the Pelangi cloth artefacts was then documented and arranged in the form of tables to identify the design features of the design through the design analysis method in Table 1, Photo Documentary of Local Traditional Pelangi Cloth Design.

Next, to find out about the types of Traditional Pelangi Cloth Motifs that are usually found on this local traditional Pelangi cloth, a study was carried out to identify the types of motifs that can be found in the textiles. In this study, 32 pieces of local traditional Pelangi cloth from the documentation of Table 1, were extracted and then placed and arrange in Figure 1 and then been analysed to identify the types of motifs that can be found in this textiles. The studies on the identification of the types of traditional Pelangi cloth motifs have been made based on various sources of reference books on Malay traditional designs and artworks. Among the books that have been referred is Motif dan Ornamen Melayu (Malay Motifs and Ornaments), (Sinar,1993), Motif-motif Etnik Malaysia (Malaysian Ethnic Motifs), (Kraftangan Malaysia, 1982), Songket Malaysia (Malaysia Songket), (Nawawi, 2002) Corak dan Ragi Tenun Melayu Riau (Malay Riau Weaving Motive and Design), (Malik, Effendy, Junus, \& Thaher, 2003), Teks Lengkap Pendidikan Seni Visual (Visual Art Education Complete Texts) (Samah, 2004), Motif Alam dalam Batik dan Songket Melayu (Nature Motifs in Malay Songket and Batik), (Hussin, 2006) and Rupa dan Gaya Busana Melayu (Malay Costume Style and Form), (Aziz, 2006). To obtain the confirmation and validation of the data on Table 1 and Table 2, the researcher conducted a personal communication, with few of handicraft trainer of Weaving and Batik at the National Craft Institute, Kuala Lumpur. Who are familiar with the local traditional textile motifs, especially the Songket motifs. (Y. Yusof, N. Abdullah, N. Johan, Z. Kassim, K. Abdullah, A. Ibrahim and A. Saari, personal communication, March 10, 2011).

Table 1: Photo Documentary of Local Traditional Pelangi Cloth Design.

\begin{tabular}{llll|}
\hline Pelangi Cloth Artefact from Malaysia State Museums and Gallery & Column A ( $\mathrm{t})$ & Column B (t) \\
\hline Pelangi Cloth from Kelantan State Museum & & \\
\hline Pelangi Cloth from Selangor State Museum & & \\
\hline
\end{tabular}


Pelangi Cloth from the National Textile Museum

Pelangi Cloth from Terengganu State Museum
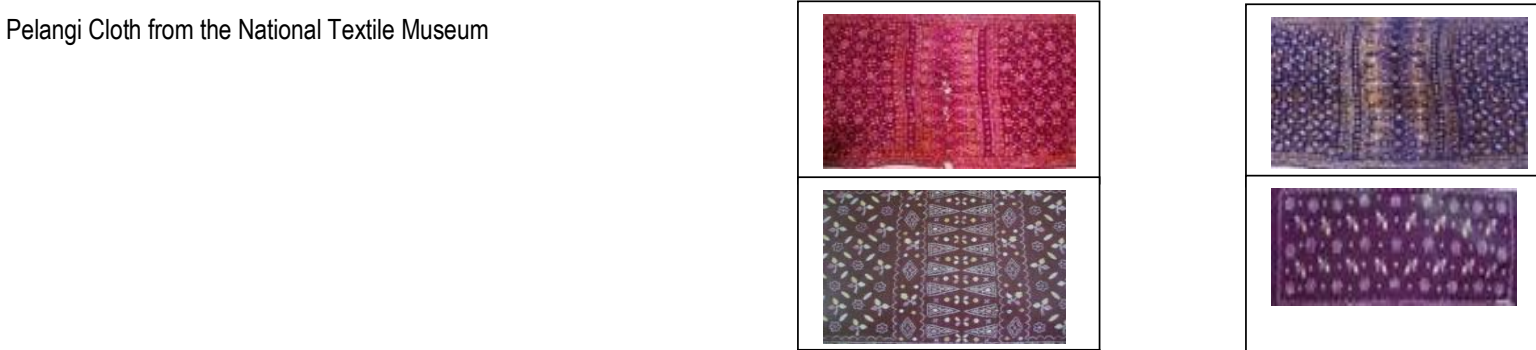

Pelangi Cloth from Terengganu State Museum
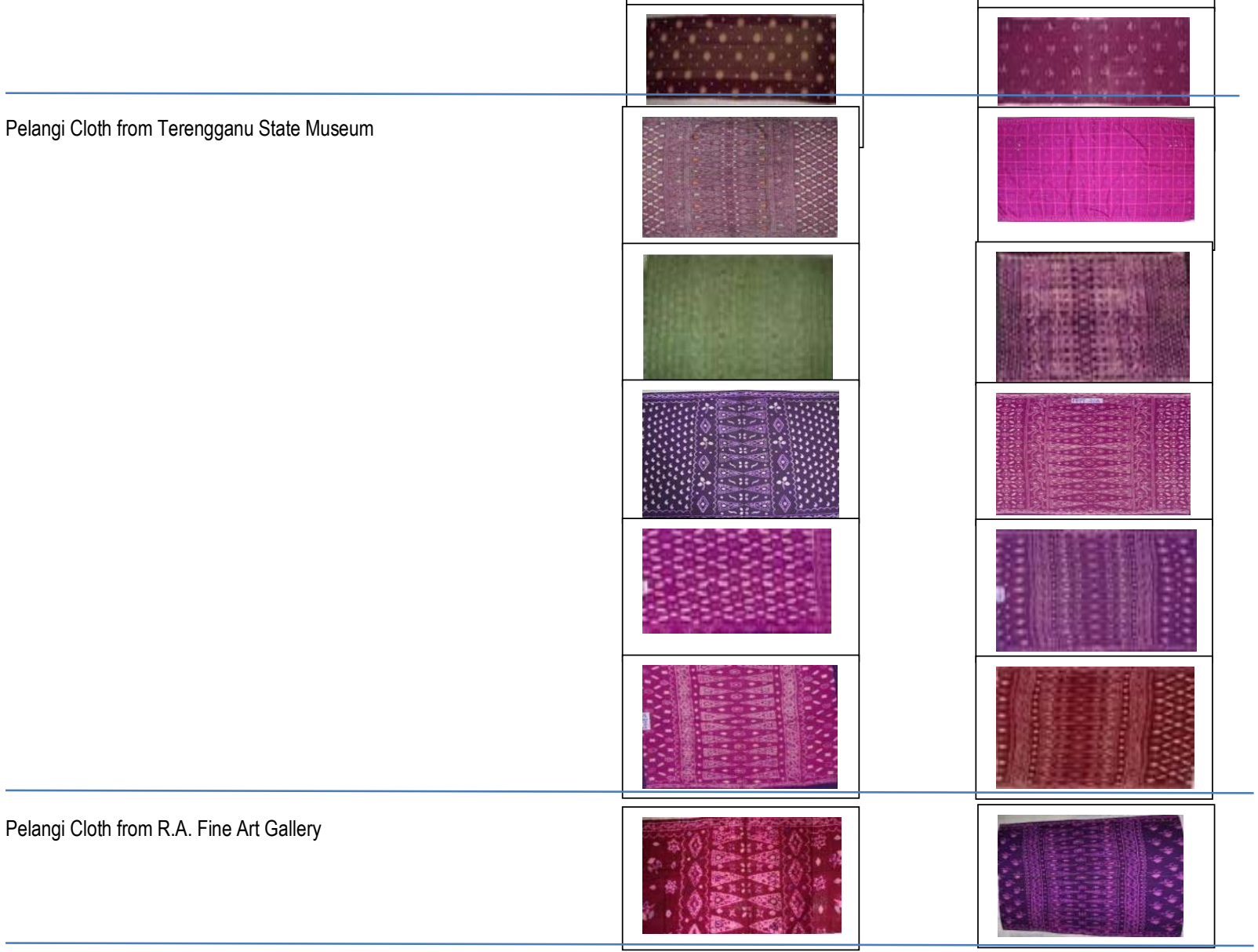

(Source: Researcher Personal Photo Collection)

\subsection{Finding}

The finding of the research through the design analysis method on the local traditional Pelangi cloth artefacts based on Table 1, Photo Documentary of Traditional Pelangi Cloth Design, shows that this textile has some specific design features. The design features identified in the artefacts are the cloth structures, the motifs, the design layout, the colour, the technique and the product. Referring to Samin (2015) states that, the inspiration of various types of the motifs on local traditional Pelangi cloth come from the observation and research of ancient Malay textile designers on nature and the elements of the objects in their own lives. This shows that the Malay identity of the textile community has been very close to nature and their daily activities. In this study, 32 pieces of local traditional Pelangi cloth from the documentation Table 1, were extracted and then placed and arrange in Table 2 and then been analysed to identify the types of motifs that can be found in this textiles. Table 2 below shows certain similarity and also differences in how the design of the motifs that discovered from the Pelangi cloth and Songket.

Table 2:s is: Similarity of Types of Motifs between Local Traditional Pelangi Cloths with Local Traditional Songket Cloth

\begin{tabular}{|c|c|c|c|}
\hline Item & $\begin{array}{c}\text { Local Pelangi cloth } \\
\text { types of Motifs } \\
\text { Form and Shape }\end{array}$ & $\begin{array}{c}\text { Local Songket Cloth } \\
\text { types of Motifs } \\
\text { Form and Shape }\end{array}$ & Name of The Motifs \\
\hline
\end{tabular}




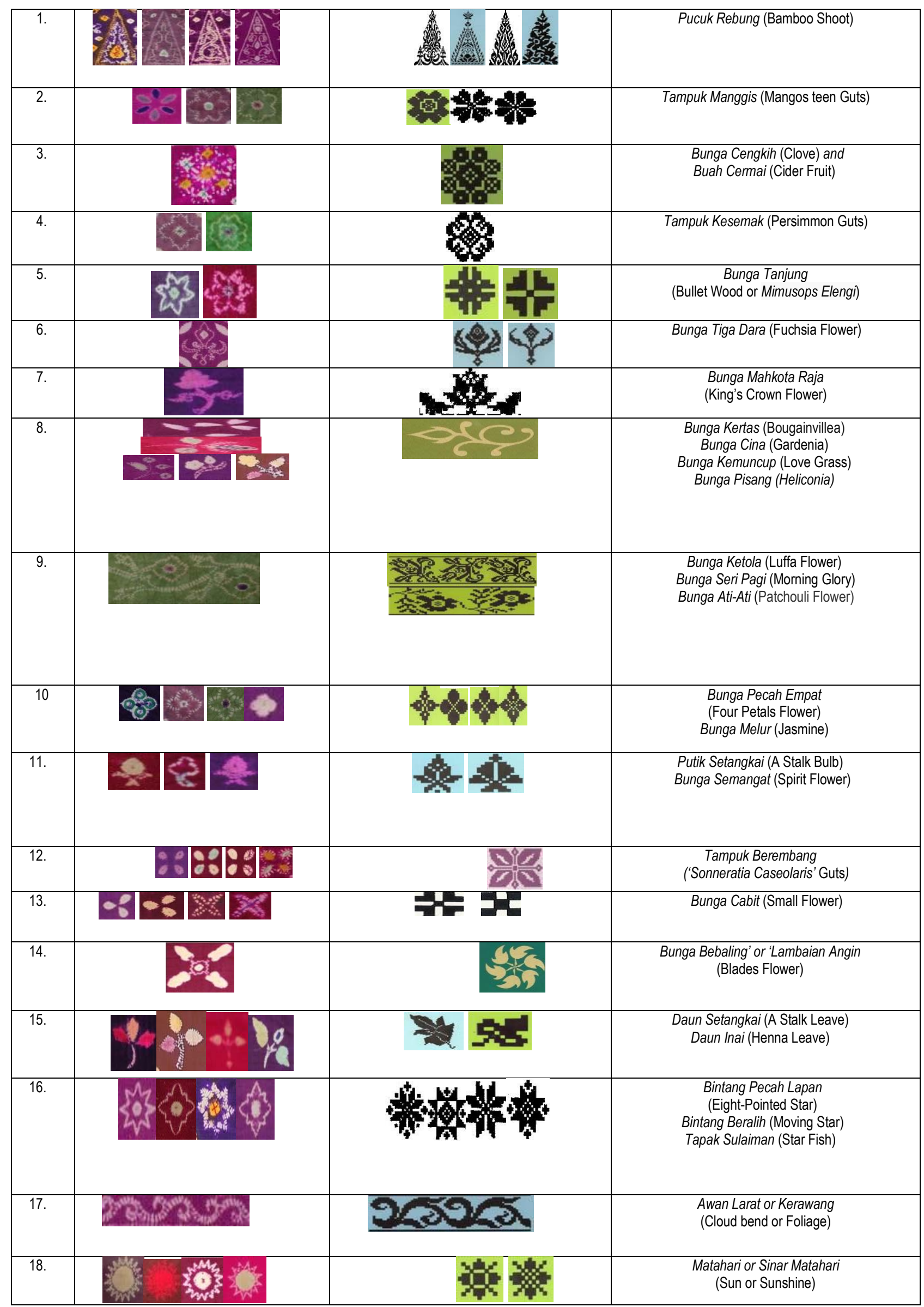




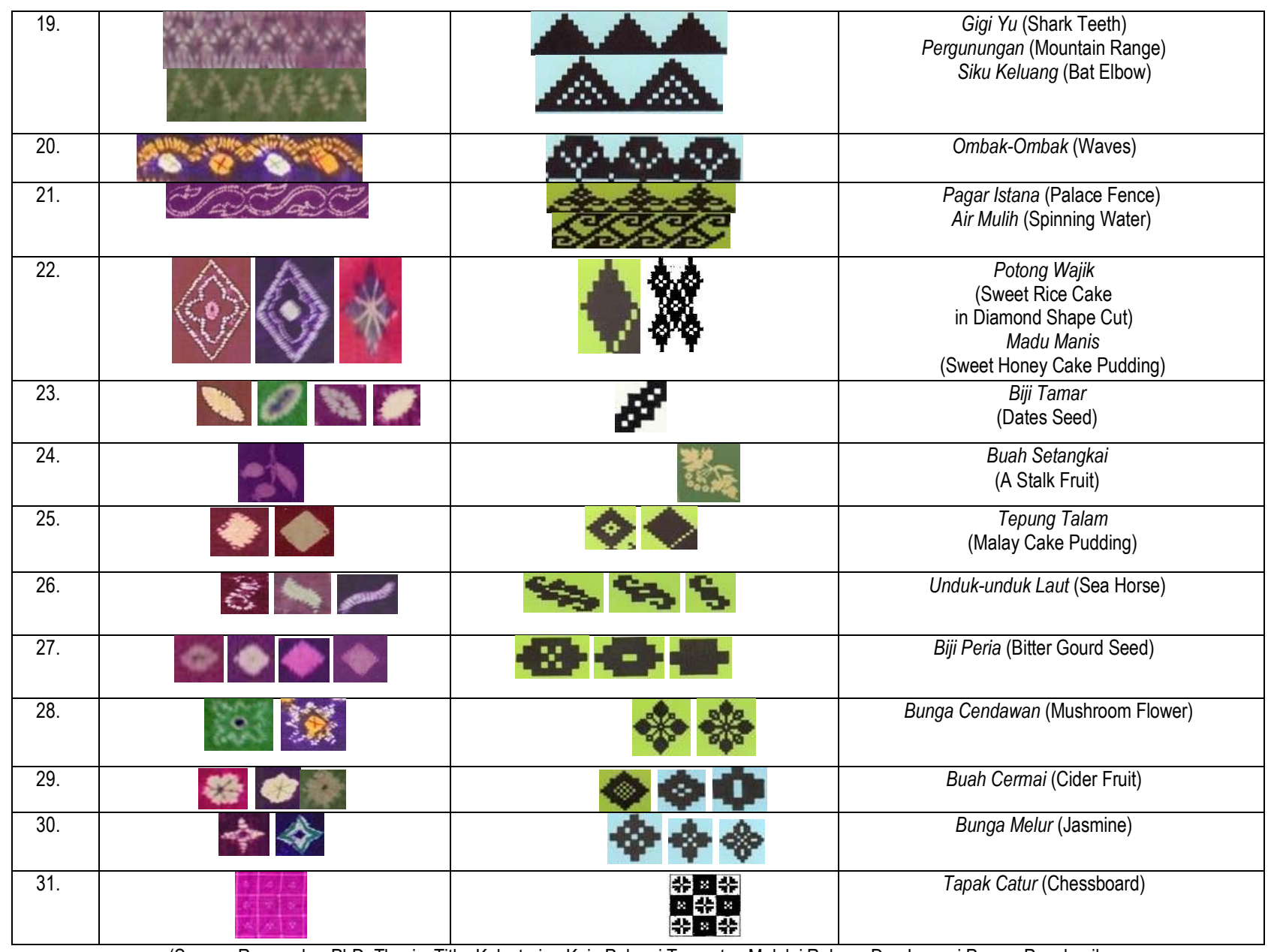

(Source: Researcher PhD. Thesis, Title: Kelestarian Kain Pelangi Tempatan Melalui Rekaan Dan Inovasi Proses Penghasilannya (Sustainability of The Local Pelangi Cloth Through the Design and Its Innovation Production Process), pp. 87- 95, 2015)

\subsection{Discussion}

Based on Table 1, Photo Documentary of Traditional Pelangi Cloth Design shows that this textile has some specific design features. The Pelangi Cloth Fabric Structure -isepiTraditional Pelangi cloth is one of the traditional textiles of the Malay community. Most local traditional Pelangi Cloth outcome is produced in the form of sarongs. In general, the sarongs of the Malay usually have a certain cloth structure. The cloth of the Malay sarongs is composed of certain parts, comprise of the Kepala Kain (Cloth Head), Pengapit Kepala Kain (Cloth Head Clamp), Badan Kain or Tanah Kain (Cloth Body Or Cloth Ground) and Kaki Kain with Gigi Kain (Cloth Leg With Cloth Teeth). The same structure can also be found in any other traditional Malay sarongs such as Limar cloth, Songket cloth, Batik cloth and the Royal Pahang weaving cloth.

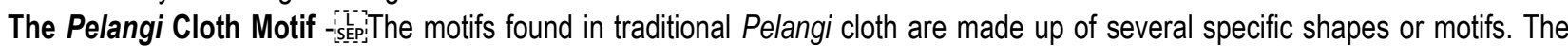
creation of the traditional Pelangi cloth motifs is a process of idea development that is inspired from a wide variety of natural objects and human-made objects found in the environment where the textile is produced. Among the motifs identified in traditional Pelangi, the cloth is Flora designs which are inspired by the appearance of flowers, leaves, fruits and parts of plants. Apart from that, there are also several Fauna designs inspired by the appearance of life creatures in the air and the water. Next are Cosmic designs inspired by the appearance of the sun and the stars. Apart from that, there are also designs of the Natural Phenomena which are inspired by the appearance of mountains, clouds and sea waves. Next is a form of traditional delicacies inspired by the appearance of Malay cakes, treats and dried fruits. There are also designs of humanmade objects which are inspired by the form of item and decoration of the palace.

The Pelangi Cloth Design Layout - Each traditional local textile usually has a design layout. The specific design layout also found in the traditional Pelangi clothes which are usually made of sarong, loose cloth (kain lepas), headband (kain pengikat kepala) and shawl (selendang). According to Samin (2011), the local Pelangi cloth design arrangement usually has the similarity with the design layout of Songket and Limar cloth. Among the design layout that is often used in traditional local Pelangi, the cloth is the design arrangement of potted flowers design arrangement (susunan corak bunga bertabur), chain bay design arrangement (susunan corak teluk berantai) and alternate design arrangement (susunan corak berselang seli). In addition, there are also chessboard design 
arrangement (susunan corak tapak catur), full or partial drop design arrangement (susunan corak turun separa) and vertical or horizontal stripe design arrangement (susunan corak berdiri atau corak melintang).

The Pelangi Cloth Colour - The colours found on the local Pelangi cloth are generally characterized as the "rainbow" state of the colours. Generally, most traditional textile researchers associate the meaning of the word Pelangi cloth referring to the rainbow colours that are often seen after the rain. The effect of the colour on the Pelangi cloth motifs is usually the result of a tapered or running stitches technique that will give the white dots around the motif. On top of that, the bound and tie technique of the motifs will provide a colourless effect which is sometimes on that colourless part occasionally coloured using paint brush technique to obtain multi-colour results. According to Abdullah via Kim (1983), In the beginning of the Pelangi cloth industry, this textile was coloured using natural colours or dyes that are produced from plants. The production process is quite traditional where the usual colours are blue and black tone with limited patterns. After the introduction of various types of synthetic dyes from Europe to Malay Peninsula in 1926, the plants dyes were then no longer used. The synthetic colours used in traditional local Pelangi cloth consisting of indogosol dye(antrasol dye and Napthol dye).

The Pelangi Cloth Technique - Traditional local Pelangi cloth are produced from a combination technique that will give the white dots around the motif with the bound and tie effects. According to Samin (2015), the production of local Pelangi cloths usually uses the technique and process of pinch with bubbling and then binding on the surface of a piece of white cloth. After that the cloth need to be soaked into the dye and let it dry and un tied which is then colour painted on the colourless part. From the result of bound tie technique, the textile production has then expanded to a wide range of techniques until it became more complex, subtle and complicated with running stitches technique for the production of Pelangi cloth.

The finding also has reveal clearly how exactly is the Design Feature of Local Traditional Pelangi Cloth especially on the types of Traditional Pelangi Cloth Motifs that are usually found in this textile. This exposition shows that there are various types of motifs inspired by the appearance of flowers, leaves, fruits and parts of the plants are often used in local traditional Pelangi cloths. Among the motifs are the motif of Pucuk Rebung (Bamboo Shoot), Tampuk Manggis (Mangos teen Guts), Bunga Cengkih (Clove Flower or Clove) Tampuk Kesemak (Persimmon Guts), Bunga Tanjung (Mimusops Elengi Flower), Bunga Tiga Dara (Fuchia Flower), Bunga Mahkota Raja (King's Crown Flower), Bunga Setangkai (A Stalk Flower), Bunga Kertas (Bougainvillea), Bunga Cina (Gardenia), Bunga Kemuncup (Love Grass), Bunga Pisang (Helicornia), Bunga Ketola (Luffa Flower), Bunga Seri Pagi (Morning Glory), Bunga AtiAti (Patchouli Flower), Bunga Pecah Empat (Four Patel's Flower) Bunga Melur (Jasmine), Putik Setangkai (A Stalk Balp), Bunga Semangat (Spirit Flower), Tampuk Beremban (Sonneratia Caseolaris Guts), Bunga Cabit (Small Flower), Bunga Bebaling or Lambaian Angin (Blades Flower), Daun Setangkai (A Stalk Leave), Daun Inai (Henna Leave), Bintang Pecah Lapan ( Eight Pointed Star), Bintang Beralih (Moving Star), Tapak Sulaiman (Star Fish), Awan Larat or Kerawang (Cloud bend or Foliage), Matahari or Sinar Matahari (Sun or Sun Shine), Gigi Yu (Shark Teeth) Pergunungan or Siku Keluang (Mountain Range or Bat Elbow) Ombak-Ombak (Waves), Pagar Istana (Palace Fence), Air Mulih (Spinning Water), Potong Wajikisepi: (Sweet Rice Cake Cut), Madu Manis (Sweet Honey), Biji Tamar (Dates Seed), Buah Setangkai (A Stalk Fruit), Tepung Talam (Malay Puding), Unduk-unduk Laut (Sea Horse), Biji Peria (Bitter Gourd Seed), Bunga Cendawan (Mushroom Flower), Buah Cermai (Cider Fruit), Bunga Melur (Jasmine), Tapak Catur (Chessboard).

The comparison shows that the motifs are also found in the local traditional Songket cloth. There is also a kind of inspired motif of the appearance of life in the air and in the water. Among these motifs are the the Siku Keluang (Bat Elbow) and Tapak Sulaiman (Star Fish) There are also a kind of inspired motifs of the appearance of the sun and the stars such as the Sinar Matahari (Sun Shine) and Bintang Pecah Lapan (Eight Pointed Star) In addition, there are also types of motives inspired by the appearance of mountains, clouds and oceans. Among these motifs are Pergunungan (Mountain Range), Awan Larat (Cloud bend) and Ombak-Ombak (Waves). There is also a types of motifs used in the design of local traditional Pelangi cloth inspired by the appearance of Malay delicacies, cakes, and dried fruits. Among the motifs are the Potong Wajik (Sweet Rice Cake Cut), Madu Manis (Sweet Honey) and Biji Tamar (Dates Seed). Then there are also types of motifs inspired by the appearance of the decoration and items found in the palace. Among these motifs are the Pagar Istana (Palace Fence) and Tapak Catur (Chessboard). The finding of this study show that since ancient times the local Malay community has had creative and artistic thinking. They are very sensitive toward art, know how to appreciate and observe the environment that is created by Allah SWT.

\subsection{Conclusion and Recommendation}

As conclusion, this study has clearly demonstrated how the local Traditional Pelangi design features. Based on Table 1, shows that the traditional Pelangi cloth design lies in its cloth structure design. This textile is decorated with the fabrication of various objects that are easily found in the environment where the textile artisan lived. Next, in terms of the design arrangement it shows the various forms of Malay traditional textile design arrangement such as scattered flower design arrangement (susunan corak bunga bertabur), chain bay design arrangement (susunan corak teluk berantai), and chessboard layout design arrangements (susunan corak tapak catur). In terms of colour, the local traditional Pelangi cloth has its distinctive colour scheme, like the 'rainbow' colours. Although initially this textile uses natural dyes and then have changed to the use of synthetic dyes however, the beauty of the textile colour scheme remains intact. The effect of the colour on the cloth motifs has been further enhanced by the bound and running stiches techniques with paint brush techniques. The composition of those techniques has highlighted the distinctive identity of this textile where it is different from the other local traditional textiles. In addition, in terms of its design, the traditional Pelangi cloth was initially designed according to the style and needs of dressing the local Malays especially to be fashionable among the noble society. Based on Table 2, clearly indicates 
that, the type of motif used in the local traditional Pelangi cloth and the traditional Songket cloth has the similarity in terms of the name and source of the motif inspired. According to Shukor (2011) via Samin (2015), has stated, in ancient times local traditional Pelangi cloth are said to be usually produced by the Songket weavers. They usually use the remnant yarns of the Songket weaving that are then woven into white plain cloth and afterwards are applied with the Pelangi cloth technique and processes. The outcome of this study have succeeded in giving a real picture of the design of local traditional Pelangi cloth that are often misinterpreted by some parties. It is also important for reference and guidance to practitioners, especially entrepreneurs, designers, lecturers and students of textile design who are interested in reproducing local traditional Pelangi cloth. Through the findings of this study, it is also evident that local traditional Pelangi cloth are distinct from the design features and motifs found in Batik cloth as well as "tie and dye" textiles introduced by Western societies around the world. The findings of this study are very important and useful to be documented in the form of scientific books or references that can be utilized by all levels of society, especially artefact textile collector, practitioners, researchers, educators and students in textile and fashion industry.

\section{Acknowledgements}

I would like to thank you to Universiti Teknologi MARA for funding this project under the grant No. 600-IRMI/DANA5/3/ ARAS(0200/2016). Special thanks to everyone who was involved in this research directly or indirectly.

\section{References}

Malik, A., Effendy, T., Junus, H., \& Thaher, A. (2003). Corak dan Ragi Tenun Melayu Riau. Yogyakarta: Penerbitan Adicita Karya Nusa.

Aziz, A. (2006). Rupa Dan Gaya: Busana Melayu. Bangi: Universiti Kebangsaan Malaysia.

Shukur, H. (2011). (temubual peribadi penyelidik, bekas pereka dan pakar tekstil tenunan Songket \& Limar di Institut Kraf Negara - April, 2011)

Hussin, H. (2006). Motif Alam Dalam Batik Dan Songket Melayu. Kuala Lumpur: Dewan Bahasa Dan Pustaka.is

Kim, K. K. (et al.). (1983). Sejarah Perusahaan Batik: Beberapa Aspek Warisan Kelantan II:Monograf Perbadanan Muzium Negeri Kelantan III, Perbadanan Muzium Negeri Kelantan Istana Jahar. Kota Bharu, Kelantan.

Kraftangan Malaysia. (1985). Motif-Motif Etnik Malaysia. Kuala Lumpur: Bahagian Dayacipta Perbadanan Kemajuan Kraftangan Malaysia.

Samin, M. A. (2011b). The Traditional Plangi Cloth Of the Malay Paninsula: A Study Of Design And Identity. Seminar Proceedings, International Textiles And Costume Congress (ITCC) 2011. ITB/CCA/ARS TEXTRINA, Bandung, Indonesia.is[i]p:

Mohd Azhar Samin (2015). Kelestarian Kain Pelangi Tempatan Melalui Rekaan dan Inovasi Proses Penghasilannya. Tesis Doktor Falsafah (PhD. - Tekstil \& Fesyen) Fakulti Seni Gunaan \& Kreatif, Universiti Malaysia Sarawak (UNIMAS).

Nawawi, N. (2002). Songket Malaysia. Kuala Lumpur: Dewan Bahasa dan Pustaka.

Sinar, T. L. SH. (1993). Motif Ornamen Melayu. Medan: Lembaga Pembinaan \& Pengembangan Seni Budaya Melayu.

Yaacob, Z. \& Samah, A. A. (2004). Teks Lengkap Pendidikan Seni Visual Tingkatan 4 \& 5. Kuala Lumpur: Penerbit Fajar Bakti Sd. Bhd. 